\title{
MEKANISME PERALIHAN HAK ATAS TANAH KARENA JUAL BELI DALAM HAL SALAH SATU PENJUAL MASIH DI BAWAH UMUR DAN PENDAFTARANNYA DI KANTOR PERTANAHAN KOTA TEGAL
}

\author{
Anjar Restu Ashari \\ Amin Purnawan
}

\begin{abstract}
Abstrak
Penelitian bertujuan untuk mengetahui bagaimana mekanisme peralihan hak atas tanah, apa saja kendala-kendala yang dihadapi dan bagai mana pemecahanya tersebut dan untuk mengetahui bagaimana perlindungan hukum bagi pihak yang terkait dalam proses tersebut.

Penelitian ini menggunakan Penelitian yuridis sosiologis merupakan penelitian yang mengkaji kaidah-kaidah hukum dan norma-norma hukum serta peraturan-peraturan yang ada, yang kemudian menganalisis dan mengkaji bekerjanya di masyarakat.bekerjanya hukum di masyarakat dapat di kaji dari tingkat efektifitasnya hukum, kepatuhan terhadap hukum, peranan lembaga atau istitusi hukum di dalam penegakan hukum, implementasi aturan hukum, pengaruh aturan hukum terhadap masalah sosial tertentu atau sebaliknya, pengaruh masalah sosial terhadap hukum.

Berdasarkan metode tersebut penelitian menghasilkan pada pokoknya perwalian dan izin menjual dapat dibuat oleh pengadilan negeri dan desa yang disahkan kecamatan, untuk pengadilan agama hanya perwalian saja. Setiap jual beli berkaitan pertanahan harus menggunakan akta jual beli dari PPAT atau PPATS. Akta tersebut sebagai bukti untuk melakukan pendaftaran di kantor pertanahan.

Masalah yang dihadapi di lapangan adalah kurang pahamnya masyarakat tentang hukum pertanahan, perwalian dan izin menjual, aplikasi pertanahan sering eror, tidak teraturnya buku warkah juga mempersulit kerja. Cara mengatasi masalah tersebut adalah dengan memberikan pengarahan hukum kepada masyarakat dan pengantian sistem warkah menjadi komputerisasi.

Mengenai perlindungan hukum bagi wali,sepanjang si-Wali dapat membuktikan bahwa harta sepanjang dipergunakan untuk kepentingan si-Anak maka, maka wali tersebut bebas demi hukum, namun berlaku sebaliknya apabila si-Wali melanggar ketentuan tersebut maka anak tersebut dapat menuntut haknya selama dapat dibuktikan sebaliknya peralihan tersebut mempunyai kekuatan hukum yang kuat (bukan mutlak).
\end{abstract}

Kata kunci : jual beli, di bawah umur, perlindungan hukum

\section{PENDAHULUAN}

\section{A. Latar Belakang Masalah}

Negara Kesatuan Republik Indonesia yang berdasarkan UUD 1945 adalah negara hukum (konstitusional) yang memberikan jaminan dan memberikan perlindungan atas hak hak warganegara untuk mendapatkan, mempunyai dan menikmati hak milik. ${ }^{1}$ Menurut Undang-undang Pokok Agraria (UUPA) atas dasar menguasai dari negara dalam pasal 2 maka menjadi kewajiban bagi pemerintah melaksanakan pendaftaran tanah di seluruh wilayah Negara Republik Indonesia.

Di dalam ketentuan Pasal 37 ayat (1) Peraturan Pemerintah Nomor 24 Tahun 1997 Tentang Pendaftaran Tanah, disebutkan setiap peralihan hak atas tanah melalui jual beli hanya dapat didaftarkan jika dapat dibuktikan dengan akta yang dibuat oleh Pejabat Pembuat Akta Tanah (PPAT). Pendaftaran hak atas tanah ini menurut ketentuan pasal Pasal 19 ayat (1) UUPA merupakan pembuktian yang kuat mengenai hapusnya hak milik serta sahnya peralihan atas tanah tersebut.

Pemahaman dari kebenaran itu bahwa dalam peralihan hak dengan jual beli atas tanah harus dilihat

\footnotetext{
${ }^{1}$ Adrian Sutedi,2016. Peralihan Hak Atas Tanah dan Pendaftaranya, Sinar Grafika Jakarta, Hlm.1
}

kedudukan hak atas tanah itu, jika hak atas tanah tersebut sebagai milik bersama maka semua yang berhak atas tanah tersebut harus sepakat dan setuju baru kemudian dilakukan transaksi jual belinya. Namun ketika salah satu pemilih hak masih di bawah umur menjadi permasalahan.

\section{B. Rumusan Masalah}

Berdasarkan uraian sebagaimana tersebut di atas maka penulis dapat merumuskan permasalahan dalam penelitian ini adalah:

1. Bagaimana mekanisme peralihan hak atas tanah karena jual beli dalam hal salah satu penjual masih di bawah umur dan pendaftarannya di Kantor Pertanahan Kota Tegal?

2. Apa problematika peralihan hak atas tanah karena jual beli dalam hal salah satu penjual masih di bawah umur dan bagaimana pemecahannya?

3. Bagaimana perlindungan hukum bagi para pihak yang melakukan peralihan hak atas tanah karena jual beli dalam hal salah satu penjual masih di bawah umur tersebut? 


\section{Pembahasan}

1. Mekanisme Peralihan Hak Atas Tanah Karena Jual Beli Dalam Hal Salah Satu Penjual Masih Di Bawah Umur

Sebelum proses jual beli yang salah satu penjualnya masih di bawah umur perlu dibuatkan perwalian dan juga izin menjual. Sistem hukum di Indonesia di kenal memiliki tiga sumber hukum yaitu hukum nasional (KUHPerdata), hukum adat dan hukum Islam.

a. Penetapan Izin Menjual dan Perwalian di Pengadilan Negeri Kota Tegal

Meskipun sudah ada perwalian untuk mewakili segala perbutan hukum yang diwalikan tetapi ketika akan melakukan kegiatan penjualan harta bagian dari si anak yang diwalikan tersebut harus dibuatkannya Izin menjual.

Kebanyakan permohonan yang di lakukan di Pengadilan Negri Kota Tegal tentang perwalian banyak yang salah memahami dari perwalian itu sendiri, karena perwalian yang diajukan adalah perwalian demi undang-undang yang otomatis, tidak diperlukanya penetapan dari pengadilan namun karena sudah dimohonkan ya dikabulkan oeleh pengadilan bersamaan dengan permohonan izin menjual. ${ }^{2}$

b. Hukum Adat

Pasal 5 UUPA tahun 1960 menyatakan bahwa:

Hukum Agraria yang berlaku atas bumi air dan ruang angkasa ialah hukum Adat sepanjang tidak bertentangan dengan kepentingan nasional dan negara, yang berdasarkan atas persatuan bangsa dengan sosialisme Indonesia serta dengan peraturan peraturan yang tercantum dalam Undang-undang ini dan dengan peraturan perundangan lainnya, serta segala sesuatu dengan mengadakan unsur-unsur yang bersandar pada hukum agama.Hukum adat sendiri berlaku hanya untuk warga pribumi semata atau warga negara indonesia asli saja. Hal ini sesuai dengan penggolongan klasifikasi hukum.

c. Hukum Islam

Perwalian menurut hukum Islam (fiqih) merupakan tanggung jawab orang tua terhadap anak.

Untuk proses yang di lakukan di pengadilan agama hanya sebatas perwalian saja, namun untuk izin menjual pengadilan agama tidak dapat membuatnya karena terkait dengan kewenagan absolut relatif pengadilan Agama.

Proses Peralihan Hak Atas Tanah Karena Jual Beli Dalam Hal Salah Satu Penjual Masih Di Bawah Umur adalah sebagai berikut :

a. Proses Pembuatan Akta Jual Beli

Dengan PP nomer 24 tahun 1997 Pasal 37(1) Peralihan hak atas tanah dan hak milik atas satuan rumah susun melalui jual beli, tukar menukar, hibah, pemasukan dalam peusahaan dan perbuatan hukum

\footnotetext{
${ }^{2}$ Wawancara Hakim Pengadilan Negeri Kota Tegal, Guntoro Eka Septi S.H, 7 Januari 2017
}

pemindahan hak lainnya, kecuali pemindahan hak melalui lelang hanya dapat didaftarkan jika dibuktikan dengan akta yang dibuat oleh PPAT yang berwenang menurut ketentuan peraturan perundang-undangan yang berlaku.

Proses pembuatan akta jual beli

- melakukan pengecekan sertipikat di Kantor pertanahan Kota Tegal

- melakukan floting. Floting adalah pencocokan kordinat dengan peta yang ada di base kator pertanahan sebagai dasar ZNT

- Penyerahan uang dari pembeli ke penjual

- pembuatan akta dan pembacaan akta

- tanda tangan akta jual beli

- melakukan penomeran akta

- melakukan verifikasi pembayaran BPHTB (pajak pembeli) dan $\mathrm{PPH}$ (pajak penjual)

b. Proses Pendaftaran di Kantor Pertanahan Kota Tegal Pemeliharaan data pendaftaran tanah dilakukan apabila terjadi perubahan pada data fisik atau data yuridis obyek pendaftaran tanah yang telah terdaftar. Pemegang hak yang bersangkutan wajib mendaftarkan perubahan sebagaimana dimaksud pada kepada Kantor Pertanahan.

Persyaratan pendaftaran peralihan hak karena jual beli dalam hal salah satu penjual masih di bawah umur. $^{3}$

1) Surat pengantar PPAT untuk melakukan pendaftaran peralihan hak

2) Surat permohonan yang di tandatangani oleh calon penerima hak dengan materai 6000

3) Surat kuasa apabila dikuasakan

4) Surat pernyataan calon penerima hak bahwa calon pemilik tidak melanggar batas kepemilikan tanah pertanian apabila obyek tanah pertanian

5) Surat perwalian dan pernyataan izin menjual atau penetapan pengadilan perwalian dan izin menjual

6) Foto copy Kartu Tanda Penduduk Penjual pembeli yang dilegalisir

7) Foto copy kartu kelurga penjual pembeli yang di legalisir

8) Foto copy Akta kelahiran yang di legalisir

9) Foto copy surat pemberitahuan pajak terutang pajak bumi dan bangunan yang di legalisir

10) Foto copy surat setoran pajak pajak daerah bea perolahan hak atas tanah dan bangunan (SSPDBPHTB) pajak pembeli

11) Foto copy setoran pajak (SSP) dan foto copy bukti pembayaran

12) Surat pernyataan siap membayar kekurangan pajak apabila ada kekurangan pembayaran dari pembeli dan bermaterai

13) Akta jual beli lembar kedua

14) Sertifikat asli

15) Permohonan ZNT
${ }^{3}$ Wawancara dengan Kasubsi PPH dan PPAT Makmur, A.ptnh 5 Januari 2017 
2. Problematika Mekanisme Peralihan Hak Atas Tanah Karena Jual Beli Dalam Hal Salah Satu Penjual Masih Di Bawah Umur Dan Pendaftaranya Di Kantor Pertanahan Kota Tegal.

Permasalahan dan pemecahanya yang terdapat di kelurahan Debong kulon adalah sebagai berikut :

1) Kurang pahamnya masyarakat tentang pemahaman hukum pertanahan

2) Sulitnya mencari warkah pertanahan di kelurahan

3) Banyak anggota keluarga yang merantau sehingga menyulitkan apabila akan dimintai tanda tangan

4) Banyak anggota keluarga yang sudah lepas dari kartu kelurga sehingga sulit mengontrol jumlah keseluruhan anggota berikut

Pemecahan permasalahan tersebut adalah sebagai

1) Memberi edukasi kepada masyarakat

2) Membenahi warkah yang berantakan

3) Pendataan warga ulang ${ }^{4}$

Permasalahan dan Pemecahannya Yang Terdapat di Pengadilan Negeri Kota Tegal adalah mengenai adalah masyarakat sering salah kaprah mengenai izin menjual dan perwalian, masyarakat salah membedekan antara kedua subtansi tersebut. ${ }^{5}$

Permasalahan dan Pemecahannya Yang Terdapat Di Kantor PPAT adalah kurang pahamnya masyarakat tentang hukum pertanahan khusunya di perwalian itu sendiri untuk mengatasi masalah tersebut memberikan penjelasan langsung terhadap klien. ${ }^{6}$

Permasalahan dan Pemecahannya yang di hadapi di kantor Pertanahan Kota Tegal. Permasalahanya adalah sebagai berikut:

1) data yang diberikan pemohon berupa foto copy KTP dan KK kurang jelas

2) Aplikasi pertanahan sering eror , sitem onlinenya

3) mencari buku warkah sulit

Pemecahannya adalah sebagai berikut:

1) meminta KTP asli dan KK asli untuk kemudian dilegalisir oleh pegawai pertanahan.

2) menambah data base ruang komputer, atau menunggu waktu malam untuk melakukan online dan menata buku tanah dengan sistem komputerisasi dengan menscan warkah satu persatu, namun belum semuanya terscan karenaterbatasnya anggaran.

\section{Perlindungan Hukum}

Selama dapat dibuktikan sebaliknya peralihan tersebut mempunyai kekuatan hukum yang kuat (bukan mutlak). sehingga pihak pihak yang terkait selama

\footnotetext{
4 Wawancara dengan Kepala Kelurahan Debong Kulon, Subardi, S.AP.,MM. 9 Januari 2017

${ }^{5}$ Wawancara Hakim Pengadilan Negeri Kota Tegal, Guntoro Eka Septi S.H, M.H 7 Januari 2017

${ }^{6}$ Wawancara dengan PPAT Kota Tegal Wiwi Hartati S.H., M.Kn. tanggal 11 Januari 2017
}

berpegang pada proses yang benar maka memiliki kekuatan hukum. ${ }^{7}$

Mengenai perlindungan hukum bagi wali, sepanjang si wali dapat membuktikan bahwa harta sepanjang dipergunakan untuk kpentingan si anak maka, maka wali tersebut bebas demi hukum, namun berlaku sebaliknya apabila si wali melanggar ketentuan tersebut maka anak tersebut dapat menuntut haknya. ${ }^{8}$

\section{Penutup}

1. Mekanisme peralihan hak atas tanah dalam hal salah satu penjual masih di bawah umur dan pendaftarannya di kantor pertanahan kota tegal dimulai dengan pembuatan perwalian dan izin menjual sebagai syarat penjual di bawah umur, yang dapat dilakuakan melalui tiga sumber hukum yaitu KUHperdata, hukum adat dan islam sedangkan untuk izin menjual hanya bisa mengunakan 2 sumber hukum KUHperdata melalui Pengadilan negeri dan hukum adat melalui desa/ kelurahan yang disahkan oleh kecamatan. setelah itu dibuatkan akta jual beli oleh PPAT/PPATS dan di daftarkan di kantor pertanahan sesuai dengan obyek tanah tersebut.

2. Problamatika mekanisme peralihan hak atas tanah karena jual beli dalam hal salah satu penjual masih di bawah umur dan pendaftaranya di kantor pertanahan kota tegal, yang ada dalam pembuatan perwalian dan izin menjual hukum adat adalah kurang pahamnya masyarakat tentang pemahaman hukum pertanahan sulitnya mencari warkah pertanahan di kelurahan banyak anggota kelurga yang merantau sehingga menyulitkan apabila akan dimintai tanda tangan, sedangkan untuk Pengadilan Negeri adalah masyarakat sering salah kaprah mengenai izin menjual dan perwalian. dalam pembuatan akta jual beli ketidaktahuan masyarakat terhadap hukum pertanahan. Untuk pendaftaran di pertanahan kota tegal kendalaya adalah data yang diberikan pemohon berupa foto copy KTP dan KK kurang jelas, Aplikasi pertanahan sering eror sitem onlinenya, mencari buku warkah sulit.

3. Mengenai perlindungan hukum bagi wali, sepanjang si wali dapat membuktikan bahwa harta sepanjang dipergunakan untuk kepentingan si anak maka, maka wali tersebut bebas demi hukum, namun berlaku sebaliknya apabila si wali melanggar ketentan tersebut maka anak tersebut dapat menuntut haknya.

\section{DAFTAR PUSTAKA}

\footnotetext{
${ }^{7}$ Wawancara Kasubsi PPH dan PPAT Makmur A.ptnh 5 Januari 2017

${ }^{8}$ Wawancara Hakim Pengadilan Negeri Kota Tegal, Guntoro Eka Septi S.H, M.H 7 Januari 2017
} 
Adrian Sutedi, 2016, Peralihan Hak Atas Tanah dan Pendaftarannya,Sinar Grafika Jakarta.

Wawancara Kasubsi PPH dan PPAT, Makmur A.ptnh 5 Januari 2017

Wawancara Hakim Pengadilan Negri Kota Tegal, Guntoro Eka Septi S.H, M.H Wawancara dengan kepala kelurahan Debong Kulon Subardi, S.AP.,MM. 7 Januari 2017

Wawancara dengan PPAT Kota Tegal Wiwi Hartati S.H., M.Kn tanggal 11 Januari 2017 